Jurnal Ilmu Dan Teknologi Kesehatan

Vol 6, No 2, Maret 2019,

ISSN: 2338-9095 (Print)

ISSN: 2338-9109 (online)

\title{
Penggunaan Media Sosial dan Aktivitas Fisik pada Remaja Tingkat Sekolah Menengah Pertama (SMP) Tahun 2018
}

\author{
Imam Waluyo ${ }^{1}$, Imas Dwi $S^{1}$, M. Arsyad Subu ${ }^{2}$, Djadjang ${ }^{1}$, Slamet $S^{1}$, Rinto Agustino ${ }^{3}$ \\ ${ }^{1}$ Universitas Binawan \\ ${ }^{2}$ Sarjah University, Dubai, Uni Emirat Arab \\ ${ }^{3}$ Pusat Studi Radian Research and Survey Indonesia \\ Email:imamw@binawan.ac.id
}

\section{Artikel history \\ Dikirim, Jan $2^{\text {nd }}, 2019$ \\ Ditinjau, Feb $9^{\text {th }}, 2019$ \\ Diterima, Feb $26^{\text {th }}, 2019$}

\begin{abstract}
Users of social networking sites are consistently logged online to communicate and interact with other users. Social networking sites are one of the most popular forms of social media, especially among teenagers, and are an alternative email as a means of instant communication between friends. This study aims to examine the Correlation between social media use with physical activity on junior high school adolescent. The study a futher analysis of previous research data with the 315 sample of Junior High School adolescent, cross sectional metode use, and Data collected using instrumen Social Networking Use Scale and Physical Activity Questionnaire for Adolescent. The result: low user of SNS with 78 student (24.8\%), average user of SNS 143 student (45.4\%), high user of SNS 81 student (25.7\%), extremely high user of SNS 13 student (4.1\%), and physical activity low activity 54 student (17.1\%), moderate activity 181 student (57.5\%), vigorous activity 80 student (25.4\%). the results show that corelation between social media use with physical activity corellation weak with $r=0.005$ stated is weak, statistically it is not significant $p=0.928(p>0.05)$. In this study, we found that there is a weak correlation between social media use with physical activity, and statistically it is not significant
\end{abstract} Keywords : adolescent, social media use, physical activity.

\begin{abstract}
ABSTRAK
Pengguna situs jejaring sosial secara konsisten login online untuk berkomunikasi dan interaksi dengan pengguna lain. Situs jejaring sosial adalah salah satu bentuk media sosial yang paling populer terutama di kalangan remaja dan menjadi alternatif email sebagai sarana untuk komunikasi instan antar teman. Penelitian ini mengkaji hubungan Antara Penggunaan Media Sosial dengan Aktivitas Fisik Pada Remaja Tingkat Sekolah Menemgah Pertama (SMP). Metode penelitian ini menggunakan analisis lanjut diambil dari penelitian sebelumnya dengan 315 sampel remaja SMP, menggunakan metode potong lintang (cross sectional) dan data dikumpulkan dengan instrumen Social Networking Use Scale dan Physical Activity Questionnaire for Adolescent. Hasil didapatkan penggunaan SNS rendah sebanyak 78 siswa (24.8\%), penggunaan rata-rata 143 siswa (45.4\%), penggunaan tinggi 81 siswa (25.7\%),
\end{abstract}


penggunaan sangat tinggi 13 siswa (4.1\%), dan pada aktivitas fisik didapatkan aktivitas rendah 54 siswa (17.1\%), aktivitas sedang 181 siswa (57.5\%), aktivitas tinggi 80 siswa (25.4\%). Hasil menunjukan bahwa hubungan antara penggunaan media sosial dengan aktivitas fisik berkolerasi lemah dengan $r=0.005$ dinyatakan lemah dan statistik hubungannya tidak bermakna $p=0.928$ ( p > 0.05 ). Dalam penelitian ini ditemukan korelasi yang lemah antara penggunaan media sosial dengan aktivitas fisik dan secara statistik tidak bermakna.

Kata Kunci: Remaja; Penggunaan Media Sosial; Aktivitas Fisik

\section{PENDAHULUAN}

Remaja yang tumbuh di abad 21 menghabiskan sebagian besar waktu meraka untuk mengakses internet melalui berbagai perangkat teknologi. Penelitian oleh Lenhert (2015) melaporkan dari remaja Amerika mengatakan mereka online setiap hari dan melaporkan bahwa mereka sedang online "hampir terus-menerus" (Havener \& Allen, 2016). Pengguna situs jejaring sosial secara konsisten login online untuk berkomunikasi dan interaksi dengan pengguna lain. Situs jejaring sosial adalah salah satu bentuk media sosial yang paling populer terutama di kalangan remaja dan menjadi alternatif email sebagai sarana untuk komunikasi instan antar teman. Situs jejaring sosial digital dioperasikan dan dibatasi dengan internet dan dapat diakses dimana saja (Alassiri, 2014; Wójcicki, Grigsbytoussaint, Hillman, \& Huhman, 2014). Indonesia layanan internet yang paling banyak diakses adalah chatting dan sosial media (APJII, 2017). Penggunaan layanan jejaring sosial seperti facebook dan twitter telah menjadi bagian populer dan integral dari komunikasi sehari-hari, remaja muda adalah pengguna yang paling antusias menggunakan jejaring sosial sebagian besar terlibat setiap hari dengan jejaring sosial melalui layar komputer atau mobile phone (Collin, Rahilly, Richardson, \& Third, 2011). Media sosial/ social media atau dikenal juga dengan jejaring sosial/ sosial network adalah sebuah media online dengan para penggunanya bisa dengan mudah berpartisipasi, berbagi, dan menciptakan isi meliputi blog, jejaring sosial, dan wiki merupakan bentuk media sosial yang paling umum digunakan oleh masyarakat dunia (Cahyono, 2016; Watie, 2011). Situs jejaring sosial membahayakan tergantung pada penggunaannya misalnya penggunaan yang berlebihan, berpotensi mempengaruhi pekerjaan individu (Olufadi, 2016). Penggunaan berlebihan situs jejaring sosial telah menciptakan risiko kesehatan yang parah karena kurangnya aktivitas fisik, rata-rata seseorang menghabiskan sekitar 9 hingga 10 jam untuk menggunakan jejaring sosial (Parvathy, 2015). Sementara itu tingkat aktivitas fisik menurun drastis selama masa remaja, tingkat paparan waktu layar (screen time) meningkat secara 
signifikan, diperkirakan di seluruh dunia menunjukan bahwa remaja tidak mencapai rekomendasi kesehatan masyarakat stidaknya 60 menit per hari moderate-tovigorous physical activity (MVPA) (Añez et al., 2016). Remaja menghabiskan 20 jam per minggu dalam aktivitas yang tidak banyak bergerak. (Lebres, 2014). Ketidakaktifan aktivitas fisik secara signifikan meningkatkan risiko penyakit kronis dan kematian (Zhang, 2016).

\section{METODE}

Analisis lanjut diambil dari penelitian dengan judul "Gambaran Penggunaan Media Elektronik terhadap Kesehatan Fisik, Kesehatan Mental, dan Akademik Sekolah pada Remaja Tingkat Sekolah Menengah Pertama (SMP) di Kecamatan Kramat Jati, Jakarta Timur, DKI Jakarta Tahun 2018” Di lakukan dengan menggunakan metode potong lintang (cross sectional), yang bertujuan untuk mengkaji Hubungan Antara Penggunaan Media Sosial dengan Aktivitas
Fisik pada Remaja Tingkat Sekolah Menengah Pertama (SMP) di Kecamatan Kramat Jati, Jakarta Timur, DKI Jakarta dan mempunyai media sosial. Sampel yang ada dalam proposal induk akan dipergunakan dengan menghitung kebutuhan sampel minimal sesuai dengan variabel hubungan antara penggunaan media sosial dengan aktivitas fisik, koefisien korelasi pearson (r) $=0.16$ (penggunaan jejaring sosial terhadap aktivitas fisik) (Macdonald-wallis, Jago, \& Sterne, 2012). Berdasarkan perhitungan sampel, sampel minimum yang didapat sebanyak 305 sampel dan data yang tersedia sebanyak 315 sehingga semua data dilakukan analisis.

\section{HASIL DAN PEMBAHASAN}

Variabel yang diteliti pada penelitian ini adalah variabel penggunaan media sosial dengan aktivitas fisik di lakukan dengan analisa univariat untuk melihat karakteristik subyek penelitian.

Tabel 1. Rata-rata, Standar Deviasi, Nilai Minimum, Nilai Maksimum, dan CI 95\%, Penggunaan media sosial dan aktivitas fisik pada remaja tingkat Sekolah Menengah Pertama (SMP) (N:315)

\begin{tabular}{lllll}
\hline Variabel & $\bar{x} \pm$ SD & Min & Max & CI 95\% \\
\hline Penggunaan Media Sosial & $12.35 \pm 3.673$ & 5 & 22 & $11.94-12.75$ \\
Aktivitas Fisik & $20.64 \pm 4.65$ & 11 & 35 & $20.12-21.15$ \\
\hline
\end{tabular}


Berdasarkan tabel 1 dapat dilihat nilai ratarata penggunaan media sosial dan aktivitas fisik. Rata-rata penggunaan media sosial adalah 12.35 \pm 3.673 dengan taraf kepercayaan 95\% (CI 95\%) antara 11.9412.75, dan rata-rata aktivitas fisik adalah $20.64 \pm 4.65$ dengan taraf kepercayaan 95\% (CI 95\%) antara 20.12-21.15. Untuk melihat sebaran data secara kualitatif, setiap variabel dikatagorikan masing-masing.
Penggunaan media sosial dikatagorikan dalam penggunaan SNS rendah bila skor 59, penggunaan rata-rata skor 10-14, penggunaan tinggi skor 15-19, dan penggunaan SNS sangat tinggi skor $\geq 19$, dan untuk aktivitas fisik dikatagorikan aktivitas rendah bila skor $\leq 2$, aktivitas sedang skor $\geq 2$ dan $\leq 3$, dan aktivitas tinggi skor $>3$.

Tabel 2. Distribusi Frekuensi penggunaan media sosial dan aktivitas fisik pada remaja tingkat Sekolah Menengah Pertama (SMP) (N:315)

\begin{tabular}{ccc}
\hline Karakteristik & Frekuensi (n) & $\begin{array}{c}\text { Presentase (\%) } \\
\text { Total }\end{array}$ \\
\hline Penggunaan Media Sosial & $\mathbf{3 1 5}$ & $\mathbf{1 0 0}$ \\
Penggunaan SNS Rendah & $\mathbf{7 8}$ & $\mathbf{2 4 . 8}$ \\
Penggunaan SNS Rata-rata & $\mathbf{1 4 3}$ & $\mathbf{4 5 . 4}$ \\
Penggunaan SNS Tinggi & $\mathbf{8 1}$ & $\mathbf{2 5 . 7}$ \\
Penggunaan SNS Sangat Tinggi & $\mathbf{1 3}$ & $\mathbf{4 . 1}$ \\
Aktivitas Fisik & & \\
Aktivitas Rendah & $\mathbf{5 4}$ & $\mathbf{1 7 . 1}$ \\
Aktivitas Sedang & $\mathbf{1 8 1}$ & $\mathbf{5 7 . 5}$ \\
Aktivitas Tinggi & $\mathbf{8 0}$ & $\mathbf{2 5 . 4}$ \\
\hline
\end{tabular}

Berdasarkan tabel 2 diatas dapat dilihat jumlah sampel yang digunakan sebanyak 315, pada variabel penggunaan media sosial, penggunaan SNS rendah sebanyak 78 siswa $(24,8 \%)$ penggunaan rata-rata 143 siswa (45.4\%), penggunaan tinggi 81 siswa $(25.7 \%)$, penggunaan sangat tinggi 13 siswa (4.1\%), dan untuk variabel aktivitas fisik, aktivitas rendah 54 siswa (17.1\%), aktivitas sedang 181 siswa (57.5\%), aktivitas tinggi 80 siswa $(25.4 \%)$. Uji normalitas untuk melihat normalitas suatu populasi atau sampel. Uji normalitas diaplikasi dengan menggunakan kolmogorov-smirnov. dengan hasil sebagai berikut : 
Imam W, Imas DS ${ }^{1}$, M. Arsyad $S^{1,3}$, Djadjang ${ }^{1}$, Slamet $S^{1}$, Rinto A., Penggunaan Media Sosial

Tabel 3. Uji Normalitas Hubungan Antara Penggunaan Media Sosial dengan Aktivitas Fisik pada Remaja Tingkat Sekolah Menengah Pertama (SMP)

\begin{tabular}{ccc}
\hline Variabel & $\mathbf{p}$ & Keterangan \\
\hline Penggunaan Media Sosial & $\mathbf{0 . 0 0 2}$ & $\begin{array}{c}\text { Distribusi Tidak } \\
\text { Normal }\end{array}$ \\
Aktivitas Fisik & & Distribusi Tidak \\
& $\mathbf{0 . 0 0 3}$ & Normal \\
\hline
\end{tabular}

normalitas

**uji

menggunakan kolmogrov-smirnov

Pada tabel 3 diatas menunjukan hasil uji diuji dengan menggunakan spearman Test. normalitas dari kedua variabel berdistribusi Adapun hasil korelasi sebagai berikut. tidak normal dengan $\mathrm{p}<0.05$, sehingga

Tabel 4. Hubungan Antara Penggunaan Media Sosial dengan Aktivitas Fisik pada Remaja Tingkat Sekolah Menengah Pertama (SMP)

\begin{tabular}{ccc}
\hline & \multicolumn{2}{c}{ Aktivitas Fisik } \\
\hline Penggunaan Media Sosial & r & p \\
& 0.005 & 0.928 \\
\hline
\end{tabular}

*test menggunakan uji korelasi spearman test

Berdasarkan tabel di atas, hasil uji korelasi lemah dengan penilaian nilai korelasi menunjukan nilai $r=0.005$ dengan apabila $r=>0.25$ dinyatakan kuat dan nilai $r$ didapatkan hubungan penggunaan media $\quad=<0.25$ dinyatakan lemah. dan statistik $\mathrm{p}=$ sosial dengan aktivitas fisik berkolerasi $0.928(\mathrm{p}>0.05)$ tidak bermakna.

Tabel 5. Tabulasi silang antara penggunaan media sosial dengan aktivitas fisik.

\begin{tabular}{lcccccc}
\hline & \multicolumn{5}{c}{ Aktivitas Fisik } \\
\cline { 2 - 7 } \multicolumn{1}{c}{ Variabel } & \multicolumn{2}{c}{ Rendah } & \multicolumn{2}{c}{ Sedang } & Tinggi \\
\cline { 2 - 7 } & $\mathrm{n}$ & $\%$ & $\mathrm{n}$ & $\%$ & $\mathrm{n}$ & $\%$ \\
\hline Penggunaan Rendah & 14 & 17.9 & 49 & 62.8 & 15 & 19.2 \\
\hline Penggunaan Rata-rata & 22 & 15.4 & 78 & 54.5 & 43 & 30.1 \\
\hline Penggunaan Tinggi & 16 & 19.8 & 49 & 60.5 & 16 & 19.8 \\
\hline Penggunaan Sangat Tinggi & 2 & 15.4 & 5 & 38.5 & 6 & 46.2 \\
\hline
\end{tabular}


Berdasarkan tabel 5 di atas dapat dilihat bahwa dari 315 sampel yang digunakan hasil tabulasi silang yang paling besar adalah penggunaan SNS rata-rata dengan aktivitas fisik sedang dengan jumlah 78 siswa dan 54.5\%. Dari hasil subjek penelitian didapatkan hasil bahwa hubungan penggunaan media sosial dengan aktivitas fisik menunjukan korelasi lemah dan secara statistik tidak bermakna. Secara kualitatif hal tersebut sesuai dengan penelitiaan sebelumnya yang menyatakan bahwa hubungan penggunaan media sosial atau jejaring sosial dalam mempengaruhi ketaatan terhadap rekomendasi aktivitas fisik pada remaja menghasilkan hasil yang tidak signifikan. Kemungkinan adanya perbedaan dari hasil penelitian dengan faktor lainnya, misalnya pada faktor dukungan sosial yang mempengaruhi penggunaan media sosial dengan aktivitas fisik dimana dibab sebelumnya membahas bagaimana dukungan sosial dapat mempengaruhi penggunaan media sosial dengan aktivitas fisik, dukungan sosial sebagai sumber emosional, informasional atau pendampingan yang diberikan oleh orang-orang sekitar individu untuk menghadapi setiap permasalahan dan krisis yang terjadi sehari-hari dalam kehidupan sehingga sesuai dengan penerapan pola asuh yang dapat diberikan oleh orang tua pada anaknya. Pola asuh diperlukan untuk menghadapi perkembangan teknologi saat ini dimana pola asuh yang benar dapat mengatasi penggunaan internet yang bersifat negatif oleh karena itu dibutuhkan keterkaitan atau hubungan penggunaan media sosial dengan dukungan sosial yang lebih jelas dalam penelitian selanjutnya dibutuhkan penelitian longitudinal untuk bisa melihat hubungan sebab akibat pada penelitian selanjutnya dan diperlukan adanya penelitian meneganai faktor-faktor lain yang dapat mempengaruhi variabel penelitian.

\section{SIMPULAN}

Didapatkan bahwa hubungan antara penggunaan media sosial dengan aktivitas fisik pada remaja di kecamatan Kramat Jati, Jakarta Timur berkolerasi lemah $(r=0.005)$ dan secara statistik hubungan tidak bermakna $(p=0.928)$.

\section{UCAPAN TERIMA KASIH}

Terima kasih kepada Program Studi Fisioterapi, Universitas Binawan yang telah memberikan fasilitas dan menyukseskan penelitian ini.

\section{DAFTAR RUJUKAN}

Alassiri, A. A. 2014. Usage of Social Networking Sites and Technological Impact on the Interaction-School of Applied Physics, 4 (4), 46-61.

Añez, E., Fornieles-Deu, A., Fauquet-Ars, J., López-Guimerà, G., Puntí-Vidal, J., \& Sánchez-Carracedo, D. 2018. Body image dissatisfaction, physical activity 
Imam W, Imas DS $S^{1}$, M. Arsyad $S^{1,3}$, Djadjang ${ }^{1}$, Slamet $\boldsymbol{S}^{1}$, Rinto A., Penggunaan Media Sosial 166 dan Aktivitas Fisik pada Remaja Tingkat Sekolah Menengah Pertama (SMP) Tahun 2018

and screen-time in Spanish adolescents. Journal of Health Psychology, 23 (1), 36-47.

APJII. 2017. Penetrasi \& Perilaku Pengguna Internet Indonesia 2017. Asosiasi Penyelenggara Jasa Internet Indonesia, 1-39.

Cahyono, A. S. (2016). Pengaruh Media Sosial Terhadap Perubahan Sosial Masyarakat di Indonesia. Jurnal Ilmu Sosial Dan Ilmu Politik Diterbitkan Oleh Fakultas Ilmu Sosial Dan Politik, Universitas Tulungagung, 9(1), 140-157.

Collin, P., Rahilly, K., Richardson, I., \& Third, A. 2011. Literature Review: The Benefits of Social Networking Services. $Y A W-C R C$ "s partner organisations.129

Havener, L. S., \& Allen, N. B. 2016. networking site usage on the mental health by Presented to the Department of Psychology, 1-31.

Lebres, V. F. 2014. Adolescents' 'Nutrition and Physical Activity Knowledge and Practices. Research Center in Physical Activity, Health and Leisure. 1-234.

Macdonald, W. K., Jago, R., \& Sterne, J. A. C. 2012. Social Network Analysis of Childhood and Youth Physical Activity. AMEPRE, 43(6), 636-642.

Olufadi, Y. 2016. Social networking time use scale (SONTUS): A new instrument for measuring the time spent on the social networking sites. Telematics and Informatics, 33 (2), 452-471.

Parvathy, J. (2015). Impact of Usage of Social Networking Sites on Youth, 129 (3), 33-34.

Watie, E. D. S. 2011. Komunikasi dan media sosial (communications and social media). The Messenger, 3 (1),
69-75.

Wójcicki, T. R., Grigsby-toussaint, D., Hillman, C. H., \& Huhman, M. 2014. Promoting Physical Activity in LowActive Adolescents via Facebook: A Pilot Randomized Controlled Trial to Test Feasibility Corresponding. JMIR Res Protoc . 3 (4), 1-15

Zhang, J., Brackbill, D., Yang, S., Becker, J., Herbert, N., \& Centola, D. 2016. Support or competition? How online social networks increase physical activity: A randomized controlled trial. Preventive Medicine Reports, 4, 453458.

Zhang, N. 2016. Viral buzz on social network sites about physical activity: Fad or fabulous? Dissertation Abstracts International: Section B: The Sciences and Engineering, 77 (2), 1-188. 